is 38 years of age and healthy; III -9 , was affected ; III-10, was an unaffected sister who died in infancy; III-11, Marie, is healthy, 23 years of age and unmarried; III-12, Doris, 22 years of age, is recently married; III-13, John Stanley D. and III-14, H. D., have both been affected as described. There are as yet no members of a generation following that of my patient.

Remarks:-My patient $\mathrm{H}$. D. is evidently an example of the syndrome of obesity, hypogenitalism, mental retardation, and retinal pigmentary disturbance described by Laurence and Moon.4 He does not exhibit the paraplegia ${ }^{3,5}$ which eventually developed in their cases, and indeed this seems to have been a feature peculiar to the original family described. ${ }^{2}$ The association of polydactyly has been noted by many observers, including Biedl and Raab,1 and recently Cockayne, Krestin, and Sorsby. ${ }^{2}$ The inheritance is not sex-linked, is of the recessive Mendelian type, probably the result of mutations of two or more genes in the same chromosome, and an example of linkage of genes. ${ }^{2}$ Although details are not complete, it does not seem unwarranted to assume that in the sibship described in this paper, the patient's deceased brother and sister with polydactyly also suffered from the "Laurence-MoonBiedl" syndrome.

I should like to thank Messrs. A. D. Griffith, O. R. M. Kelly, D. G. Sharp, and A. Sorsby for their kind advice and assistance in the preparation of this report.

\title{
REFERENCES
}

1. Biedl, A., and Raab, W.-Deutsch. med. Wochenschr., Leipz., Vol. XLVIII, ii, p. 1630, 1922; Wien. Arch.f. inn. med., Vol. VII, p. 443, 1924.

2. Cockayne, E. A., Krestin, D., and Sorsby, A.-Quart. Journ. Med., pp. 93120, April, 1935.

3. Hutchinson, J.-Ophthal. Rev., Lond., Vol. I, p. 28, 1882; Hutchinson's Arch. Surg., Lond., Vol. XI, p. 118, 1900.

4. Laurence, J. Z., and Moon, R. C.-Ophthal. Rev., Lond., Vol. II, pp. 32-41, 1866.

5. Nettleship, E.-Ophthal. Hosp. Repts., Vol. XVII, p. 371, 1908.

\section{THE PRECISE ORIGIN OF CORNEAL PITTING}

BY

Lieut.-Col. H. Herbert, I.M.S. (Retd.)

IN the July, 1935, issue of the Brit. Jl. of Ophthal. MacCallan draws the unqualified conclusion, from a short paper published by me two months earlier in the same journal, that I am "not in agreement with the view that follicles are the antecedents of Herbert's peripheral pits." 
I regret that this sweeping deduction could have been drawn from my remarks. Anyone with large Eastern ophthalmic experience must agree without hesitation, as I do, that all the more obvious marginal post-trachomatous corneal depressions indicate the sites of former cell aggregations, whether typically follicular in the arrangement of their cells, or not.

But this recognition does not carry us anywhere near the root cause of pitting in general. It does not explain the restriction in the sites of the depressions to a single row near the upper corneal border. And it pays no regard to the fact that the uncommon, particularly arresting, and noticeable deep pits, representing earlier follicles, constituted only the major examples of a series of depressions, mostly minimal, that were thrust into notice in India by a commonly associated abnormal pigmentation of the spots. In the majority of these closely related cases cell accumulation must have been scanty throughout.

It is in the nature of a paradox that the more definitely destructive lesions-the deeper pits-should have been traceable in India, with the aid of this localized pigmentation, through lower grade lesions back to a presumptive origin at points showing precisely the reverse evidences, namely, to primary localized marginal resistances against pannus invasions. This seems an extraordinarily complete reversal.

It is accepted that trachoma is not always persistently progressive. But one loses touch with the mild and short-lived cases, which should serve to provide permanent clinical records of the initial and immediately following steps in trachomatous developments.

'Thus the very small, clear and sharply defined notches, cut into the ill defined lower border of old minimal pannus remains, to be seen in No. 12 of the small outline drawings published with my original paper (Trans. Ophthal. Soc., U.K., XXIV, 1904), constituted a rare finding. It provided a valuable, much needed, lasting record of the initial, purely resistant phase.

But without definite "outside" support, such rare trachomatous evidences of the existence of isolated points along the upper corneal border, resistant to superficial inflammatory invasion, would be unconvincing.

Fortunately this needed clinical support is forthcoming. The cases are rare, but this is as it should be. Apparently only exceptional eyes are capable of developing either the trachomatous or the non-trachomatous evidences of resistance.

I can recall vaguely a few instances of diffuse superficial inflammatory haze of the cornea, showing an upper row of sharply 
defined, somewhat clearer round spots. The general impression conveyed was that of an exceptional corneal involvement in a mild insignificant conjunctivitis. The less clouded points appeared slightly depressed.

Being by no means striking, the spots might have escaped casual observation and, their clinical course being probably shortlived, opportunities for recognizing them must have been correspondingly limited. Almost their sole interest lay in the much needed support, which they have given, to the more striking and progressive related trachomatous developments.

Reference to my original (1904) paper shows that, at the reading of the paper, I tried to demonstrate a corresponding row of barely perceptible corneal depressions in a case of interstitial keratitis. The demonstration was naturally feeble, showing a superficial result of an inflammatory process that was mainly deep. But the case is distinctly relevant here.

All the above varied clinical developments, ranging up to the deepest trachomatous pits, seem traceable back in some measure to the primary and fundamental influence of relatively small, exceptional, isolated limbal resistances.

The resistant notches seen in my old outline drawings Nos. 12 and $13^{*}$ represented resistances to an invasion directed downwards only, from the upper corneal border. The resistances outlined correspond with the sharply cut eddies and slack waters that are to be seen as the results of relatively small obstructions in shallow flowing waters of river or sea.

In the case of the transient catarrhal invasions the strict limitation in the sites of the clearer points, to the upper corneal border, is the only feature that connects them with the hypothetical limbal obstructions.

In progressive trachoma the still waters below limbal obstructions may well serve for the (follicular) local increase of actively eroding cells, to produce effects ranging up to the deepest pits.

I ventured to suggest the minute basal epithelial crypts as possibly providing the isolated clinical resistances. Appropriate exceptional grouping and spacing of the crypts might be responsible for the varied clinical developments. The suggestion was perhaps premature, as there is no evidence yet of such essential grouping in any eyes. It is a matter for future observation.

* Note.-The reference is not to separate isolated illustrations but merely to items among a series of over 30 little drawings. H.H. 